\title{
PENGARUH KOMPENSASI DAN PELATIHAN TERHADAP PRODUKTIVITAS KERJA PADA KARYAWAN DI PT ASABA JAKARTA
}

\author{
RONI FASLAH* \\ PUTRI INTAN ASTRINI ${ }^{*}$
}

\begin{abstract}
This Study aims to determine whether there is the influence of compensation and training towards productivity of employee in PT Asaba Jakarta. The research was conducted over two month from Mei to June 2014. The research method used is survey method with the correlation approach. From the result of Ftest, found that $F_{\text {count }}(483,263)>F_{\text {table }}(3,165)$. This means that $X_{1}$ and $X_{2}$ simultaneously affect the $Y$. T test produce $t_{\text {count }}$ of $X_{1}$ is $(1,715) \geq t_{\text {table }}(1,673)$ and $t_{\text {count }} X_{2}(17,653) \geq t_{\text {table }}(1,673)$. Because $t_{\text {count }} \geq t_{\text {table }}$, it can be concluded that there is a influence on the job insecurity and organization commitment towards turnover intention. Then a coefficient of determination of test results obtained 0,946 or $94,6 \%$ variable $Y$ determined by $X_{1}$ and $X_{2}$. Based on the result of regretion model, regression equation obtained is $\hat{Y}=0,384+2,644 \mathrm{X}_{1}+$ $7,010 \mathrm{X}_{2}$. Beside that, the result of $R^{2}$ eqqual to 0,946 wich means that compensation and training can explained productivity eqqual to $94,6 \%$ and $5,4 \%$ explained with another variabel.
\end{abstract}

Keywords: productivity, compensation, training, correlation, regression.

\section{PENDAHULUAN}

\begin{tabular}{lrr}
\multicolumn{2}{c}{ Manusia dalam } & sebuah \\
organisasi memiliki peran & sentral \\
untuk menggerakan & roda \\
perkembangan dan & laju \\
produktivitas organisasi. & Kualitas
\end{tabular}

* Roni Faslah. Fakultas Ekonomi Universitas

N* Negeri Jakarta.

** Putri Intan A. Fakultas Ekonomi Universitas Negeri Jakarta sumber daya manusia mempunyai pengaruh yang signifikan dengan kemampuan dan kemajuan organisasi.

Satu hal yang harus diperhatikan adalah keberhasilan berbagai aktivitas di dalam perusahaan dalam mencapai tujuan perusahaan tidak hanya tergantung 
pada keunggulan teknologi, dana operasi yang tersedia, sarana ataupun prasarana yang dimiliki, melainkan juga tergantung pada aspek sumber daya manusia. Hal ini karena sumber daya manusia merupakan asset penting yang sangat berharga untuk menunjang keberhasilan organisasi.

Setiap perusahaan menghendaki semua kegiatan yang dilakukan karyawannya mempunyai hasil yang optimal atau baik. Salah satu upaya yang dapat dilakukan oleh perusahaan adalah dengan meningkatkan produktivitas karyawan, karena produktivitas merupakan bagian terpenting dalam usaha mengembangkan perusahaan ke arah yang lebih baik lagi. Banyak cara yang dapat dilakukan perusahaan untuk meningkatkan produktivitas kerja karyawan, seperti memberikan motivasi, kompensasi, pelatihan dan fasilitas yang dapat digunakan oleh karyawan saat bekerja. Dengan memberikan hal-hal tersebut diharapkan karyawan dapat bekerja secara optimal sehingga tujuan perusahaan dapat tercapai.

Produktivitas kerja merupakan tingkat keunggulan yang diharapkan untuk memenuhi keinginan konsumen. Setiap perusahaan menghendaki semua kegiatan yang dilakukan karyawannya mempunyai hasil yang optimal atau baik. Salah satu upaya yang dapat dilakukan oleh perusahaan adalah dengan meningkatkan produktivitas kerja karyawan, karena produktivitas kerja merupakan bagian terpenting dalam usaha mengembangkan perusahaan ke arah yang lebih baik lagi.

Seringkali permasalahan yang dihadapi oleh PT ASABA yaitu naik turunnya tingkat pencapaian kerja karyawan. Ini dapat terlihat pada grafik di bawah ini. 
Roni Faslah \&: Pengaruh Kompensasi dan Pelatihan Terhadap Produktivitas Kerja Pada Karyawan

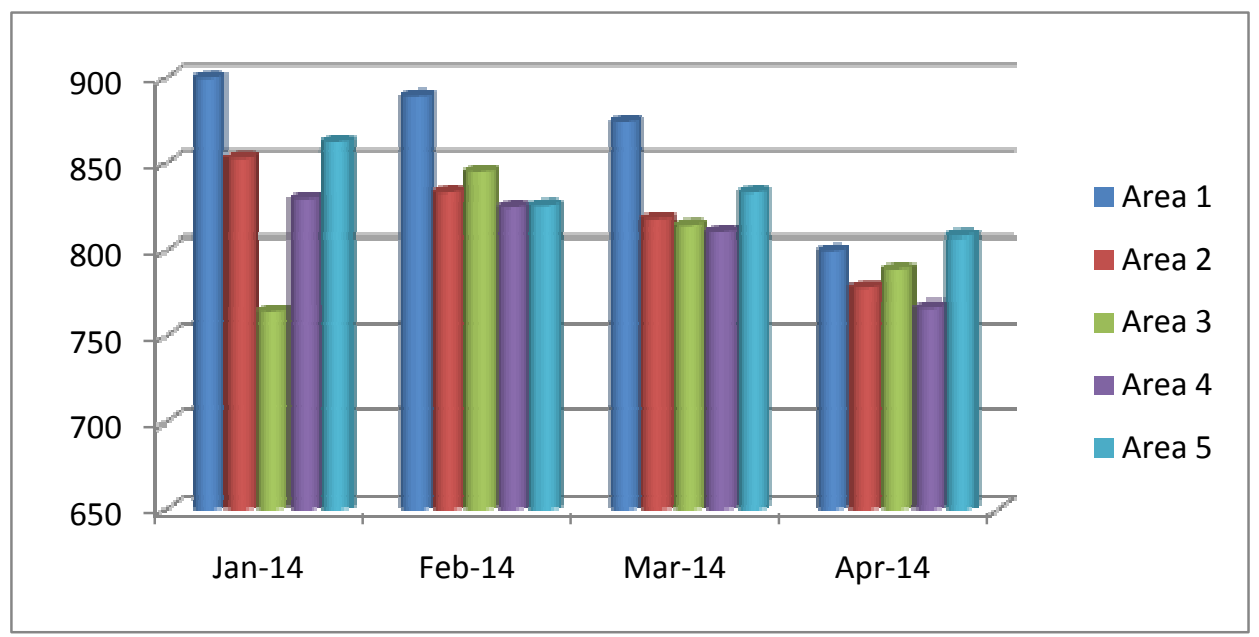

Grafik I.1

Tingkat Pencapaian Kerja

(Sumber: Data perusahaan diolah peneliti)

Seperti yang dipaparkan oleh Manager divisi teknik bahwa divisi ini memiliki target pencapaian kerja minimal sebesar 4.200 unit peralatan yang harus dipelihara (maintenance) dan diperbaiki bila ada kerusakan tiap bulannya. Peralatan kantor tersebut tersebar pada berbagai perusahaan di seluruh Jakarta. Maka perusahaan membaginya ke dalam lima area. Area 1 adalah Jakarta Timur, area 2 adalah Jakarta Barat, area 3 adalah Jakarta Pusat, Area 4 adalah Jakarta Selatan dan area 5 adalah Jakarta Utara.

Dilihat dari bagan tersebut, Bapak Winsa sebagai Manajer Divisi Teknik menjelaskan bahwa pencapaian kerja pada bulan Januari dan Februari 2014, peralatan yang mampu di-maintainance dan diperbaiki mencapai lebih dari 4.200 unit. Ini menunjukkan produktivitas kerja yang baik bagi karyawan. Sayangnya, pada bulan ketiga dan keempat, target pencapaian kerja terjadi penurunan menjadi 4.151 dan 3.942 unit saja. Ini mengindikasikan bahwa terjadi penurunan produktivitas kerja pada bulan Maret dan April kurang lebih sebesar $4,9 \%$. Sehingga ini menjadi perhatian serius bagi perusahaan agar produktivitas kerja karyawan tidak mengalami kemunduran di tiap bulannya. 
Roni Faslah \&: Pengaruh Kompensasi dan Pelatihan Terhadap Produktivitas Kerja Pada Karyawan

Ada beberapa faktor yang mempengaruhi produktivitas kerja, dua diantaranya yaitu kompensasi dan pelatihan.

Suatu kenyataan yang tidak dapat disangkal bahwa motivasi seseorang untuk bekerja di suatu perusahaan adalah mencari nafkah. Apabila seorang karyawan telah menggunakan pengetahuan, keterampilan, tenaga dan sebagian waktunya untuk berkontribusi di suatu perusahaan, maka karyawan tersebut juga mengharapkan menerima kompensasi yang adil dan sesuai atas pekerjaannya.

Tetapi pada saat ini masih ada perusahaan yang memberikan kompensasi tidak sesuai dengan hasil kerja yang telah diberikan oleh karyawannya. Ketidaksesuaian antara tenaga dan pikiran yang telah diberikan dengan kompensasi yang diterimanya dapat menimbulkan reaksi negatif dari karyawan tersebut. Reaksi negatif seperti mogok kerja, tingkat absensi yang tinggi dan penurunan produktivitas merupakan reaksi yang sering dilakukan oleh karyawan. Apabila reaksi tersebut tidak cepat diatasi, kerugian yang paling besar bukan hanya dialami oleh pihak karyawan, tetapi juga pihak perusahaan, yaitu menurunnya keuntungan perusahaan yang disebabkan berhentinya kegiatan operasional perusahaan.

kalah $\begin{array}{rr}\text { Faktor terakhir yang tidak } \\ \text { pentingya dalam }\end{array}$
meningkatkan produktivitas kerja adalah pelatihan. Perusahaan mengadakan pelatihan tentunya ingin melihat seberapa besar keterampilan dan pengetahuan yang dimiliki oleh karyawan. Di dalam pelatihan, perusahaan juga memberikan nilai akhir dari pelatihan tersebut. Namun sayangnya, tidak semua karyawan memperoleh nilai dari hasil pelatihan yang tinggi. Ini menandakan bahwa ada karyawan yang memiliki keterampilan dan pengetahuan yang semakin meningkat pada saat setelah pelatihan, ada pula karyawan yang keterampilan dan pengetahuannya tidak meningkat cukup drastis pada saat setelah pelatihan. Ini akan berpengaruh pada produktivitas kerja setiap karyawan pula, ada yang semakin meningkat ada pula yang tetap (stagnan).

Walaupun perusahaan sudah memberikan program pengenalan yang sangat baik, tetapi belum menjamin para karyawan baru dapat melaksanakan tugas-tugasnya 
Roni Faslah \&: Pengaruh Kompensasi dan Pelatihan Terhadap Produktivitas Kerja Pada Karyawan

dengan memuaskan. Begitu pula dengan karyawan lama, meskipun karyawan sudah berpengalaman masih tetap memerlukan penambahan keterampilan, pengetahuan, dan keahlian karena selalu ada cara yang lebih baik untuk meningkatkan produktivitas kerja.

PT Asaba sebagai salah satu perusahaan yang bergerak sebagai distributor penyediaan peralatan kantor mempunyai tugas berat dalam memelihara dan meningkatkan pengetahuan, kemampuan dan keterampilan karyawannya agar dapat terus bersaing dengan perusahaan besar lainnya. Berdasarkan survey yang dilakukan oleh peneliti terindikasi bahwa masih banyak karyawan yang menerima kompensasi yang tidak sesuai dengan kebutuhan masing-masing karyawan. Sehingga karyawan tidak termotivasi dan semangat dalam bekerja dan berdampak kepada penurunan produktivitas kerja karyawan. Karyawan berharap dapat menerima kompensasi yang sesuai dengan kontribusi nya kepada perusahaan dan sesuai dengan kebutuhan hidupnya.

\section{KAJIAN TEORI \\ Produktivitas Kerja}

Produktivitas kerja menjadi perhatian utama dalam suatu organisasi perusahaan, karena dengan tingginya produktivitas kerja pada suatu perusahaan maka tujuan perusahaan akan tercapai. Berbagai ungkapan seperti input, output, efisiensi dan efektivitas sering dihubungkan dengan produktivitas kerja. Produktivitas kerja tidak terlepas dari adanya peran sumber daya manusia sebagai pelaksana kegiatan perusahaan itu sendiri, yaitu karyawan. Selain itu, produktivitas kerja juga berhubungan dengan sumber daya lain seperti modal, energi, mesin dan teknologi yang digunakan, apakah sudah cukup efisien dan efektif selama kegiatan perusahaan berlangsung.

Menurut Nawawi (Tjutju Yuniarsih dan Suwanto, 2011) produktivitas kerja merupakan perbandingan antara hasil yang diperoleh (output) dengan jumlah sumber daya yang dipergunakan sebagai masukan.

Menurut Prijono dan Laila (2008) produktivitas kerja diartikan sebagai rasio antara hasil (output) dengan masukkan (input) pada ukuran waktu tertentu (jam, bulan, 
Roni Faslah \&: Pengaruh Kompensasi dan Pelatihan Terhadap Produktivitas Kerja Pada Karyawan

tahun) yang menunjukkan kualitas sama atau meningkat. Sedangkan Danang Sunyoto mengemukakan bahwa produktivitas kerja diartikan sebagai ukuran yang menunjukkan pertimbangan antara input dan output yang dikeluarkan perusahaan serta peran tenaga kerja yang dimiliki per satuan waktu.

Tidak jauh berbeda halnya dengan definisi yang dikemukakan oleh John Soeprihanto (Toni Setiawan, 2012) bahwa produktivitas dapat diartikan sebagai perbandingan antara hasilhasil yang dicapai dengan keseluruhan sumber daya yang dipergunakan atau perbandingan jumlah produksi (output) dengan sumber daya yang digunakan (input).

Dengan demikian produktivitas kerja menggambarkan hubungan antara masukkan (input) yang digunakan untuk menghasilkan keluaran (output) tersebut. Keluaran (output) diperoleh dari suatu proses kegiatan. Bentuk keluaran (output) dapat berupa produk nyata atau jasa. Untuk menghasilkan keluaran (output), diperlukan masukkan (input) atau sumber-sumber utama dapat berupa tenaga kerja, modal, bahan baku, dan energi.
Fischer, Schoenfeldt, dan Shaw mengemukakan bahwa produktivitas tenaga kerja bukan sekedar merupakan fungsi dari seberapa keras karyawan berkerja, melainkan juga sangat tergantung pada lingkungan kerja dan alur proses yang dilewatinya. Misalnya kualitas pasokan bahan, rancangan kerja, perawatan mesin, penggantian (modernisasi) perlengkapan dan peralatan kerja, desain produk, proses produksi yang telah ditetapkan, serta iklim organisasi yang berkembang di dalamnya (Tjutju Yuniarsih dan Suwanto, 2011). Sama halnya dengan pendapat tersebut, Malayu Hasibuan (2010) juga berpendapat bahwa produktivitas adalah perbandingan antara output (hasil) dengan input (masukan). Jika produktivitas naik, ini hanya dimungkinkan oleh adanya peningkatan efisiensi (waktu-bahantenaga) dan sistem kerja, teknik produksi dan adanya peningkatan keterampilan dari tenaga kerjanya.

Dari pendapat di atas dapat disimpulkan bahwa jika produktivitas kerja naik, bukan hanya dilihat dari kerja keras sumber daya manusia bekerja, melainkan dengan adanya peningkatan efisiensi dalam hal 
Roni Faslah \&: Pengaruh Kompensasi dan Pelatihan Terhadap Produktivitas Kerja Pada Karyawan

waktu, bahan dan tenaga, sistem kerja, pasokan bahan, peralatan kerja, teknik dan proses produksi serta adanya peningkatan keterampilan dari tenaga kerjanya. International

Labour Orgaization (ILO) mengungkapkan bahwa secara lebih sederhana maksud dari produktivitas kerja adalah "perbandingan secara ilmu hitung antara jumlah yang dihasilkan dan jumlah setiap sumber yang dipergunakan selama produksi berlangsung.

Produktivitas memiliki dua dimensi, dimensi pertama adalah efektivitas yang mengarah kepada pencapaian unjuk kerja yang maksimal yaitu pencapaian target yang berkaitan dengan kualitas, kuantitas, dan waktu. Dan yang kedua yaitu efisiensi yang berkaitan dengan upaya membandingkan input dengan realisasi penggunaannya atau bagaimana pekerjaan tersebut dilaksanakan (Toni Setiawan, 2012).

Efektivitas berkaitan dengan performance atau pencapaian unjuk kerja yang maksimal dan efisiensi dikaitkan dengan penggunaan sumber-sumber. Tinggi rendahnya efisiensi ditentukan oleh nilai input dan output, sedangkan tinggi rendahnya nilai efektivitas ditentukan oleh pencapaian target. Dimensi efektivitas berkaitan dengan optimalisasi ketercapaian rencana (target kerja), baik dilihat dari aspek kualitas, kuantitas, durasi penyelesaian pekerjaan, dan ketepatan pengalokasian sumber daya organisasi. Pada dimensi efisiensi, pengukuran produktivitas merujuk pada realisasi penggunaan sumber daya dan bagaimana pekerjaan tersebut dilaksanakan, apakah terjadi pemborosan, penyalahgunaan atau penyimpangan alokasi sumber daya yang menimbulkan ketidaktercapaian target produk.

Dalam mengetahui naik atau turunnya tingkat produktivitas kerja karyawan, perusahaan tidak dapat melihat hanya dari satu dimensi saja, karena walaupun perusahaan telah mencapai tujuannya dengan cara yang efektif tetapi penggunaan sumber daya yang dimilikinya tidak digunakan secara efisien, maka produktivitas kerja karyawan tersebut belum dapat dikatakan mengalami peningkatan.

Akhir dari uraian mengenai produktivitas kerja dapat disimpulkan, produktivitas kerja adalah usaha terbaik yang dilakukan untuk memperoleh hasil kerja yang 
Roni Faslah \&: Pengaruh Kompensasi dan Pelatihan Terhadap Produktivitas Kerja Pada Karyawan

efektif dan efisien antara input (masukkan) dan output (hasil) untuk pencapaian tujuan perusahaan.

\section{Kompensasi}

Kompensasi merupakan hal yang penting, yang merupakan dorongan utama seorang karyawan untuk bekerja. Selain itu, kompensasi merupakan salah satu faktor penting dan menjadi perhatian pada banyak organisasi dalam mempertahankan dan menarik sumber daya manusia yang berkualitas. Hal ini berarti bahwa karyawan menggunakan pengetahuan, keterampilan, tenaga dan waktu bukan semata-mata ingin mengabdikan diri pada perusahaan, tetapi ada tujuan lain yaitu mengharapkan imbalan atau balas jasa.

Notoatmodjo mendefinisikan bahwa, kompensasi adalah segala sesuatu yang diterima oleh karyawan sebagai balas jasa untuk kerja mereka. Berdasarkan definisi di atas maka dapat disimpulkan bahwa pada saat karyawan bekerja, ia memberikan waktu, tenaga, dan pikirannya untuk menyelesaikan pekerjaannya demi kemajuan perusahaan dan untuk mencapai tujuan perusahaan. Maka dari itu, karyawan akan mendapat balas jasa dari perusahaan atas apa yang sudah dikerjakannya.

William B. Werther dan Keith Davis menyatakan bahwa, "Kompensasi adalah apa yang seorang pekerja terima sebagai balasan dari pekerjaan yang diberikannya. Sejalan dengan Handoko yang mendefinisikan kompensasi adalah "segala sesuatu yang diterima para karyawan sebagai balas jasa untuk kerja mereka". Sedangkan Edwin B. Flippo mengungkapkan pengertian kompensasi yaitu, "compensation as the adequate and equitable remuneration of personal for their contribution to organization objectives".

Sehingga dapat disimpulkan bahwa kompensasi sebagai bentuk balas jasa terhadap karyawan yang menghasilkan sesuatu atas pekerjaannya. Karyawan tersebut mendapatkan imbalan sesuai dengan kontribusinya terhadap perusahaan. Pada dasarnya, pendapat para ahli di atas adalah sama dengan menyebutkan kompensasi sebagai balas jasa atau penghargaan yang diterima karyawan setelah kontribusi yang berarti yang diberikan bagi perusahaan. 
Secara umum Sedarmayanti (2010) menjelaskan tujuan pengelolaan kompensasi yaitu:

1. Keadilan internal

Menjamin bahwa posisi yang lebih banyak persyaratannya atau orang yang lebih cakap/mampu di dalam organisasi diberi kompensasi lebih tinggi.

2. Keadilan eksternal

Menjamin bahwa pekerjaan diberi imbalan yang wajar sebanding dengan pekerjaan serupa di pasar kerja.

Kompensasi dianggap sangat penting bagi karyawan itu sendiri sebagai individu, karena besarnya kompensasi merupakan pencerminan atau ukuran nilai pekerjaan karyawan itu sendiri. Kompensasi mengindikasikan nilai yang diletakkan perusahaan pada keahlian karyawan untuk bekerja sehingga akan mendapatkan imbalan yang sebanding dengan pekerjaan yang serupa.

Ike Kusdyah (2008) menjelaskan bahwa kompensasi adalah keseluruhan balas jasa yang diterima oleh karyawan sebagai balas jasa dari pelaksanaan pekerjaan di organisasi dalam bentuk uang atau lainnya, yang dapat berupa gaji, upah, bonus, insentif, dan tunjangan kesehatan, tunjangan hari raya, uang makan, cuti, dan lain-lain.

Lebih lanjut Mangkuprawira (2004) menyatakan bahwa kompensasi merupakan sesuatu yang diterima karyawan sebagai penukar dari kontribusi jasa mereka pada perusahaan. Dengan demikian kompensasi mengandung arti tidak sekadar hanya dalam bentuk finansial saja, seperti yang langsung berupa gaji, upah, komisi, dan bonus, serta tidak langsung berupa asuransi, bantuan sosial, uang cuti, uang pensiun, pendidikan dan sebagainya tetapi juga bentuk bukan finansial. Bentuk ini berupa pekerjaan dan lingkungan pekerjaan. Bentuk pekerjaan berupa tanggung jawab, perhatian, kesempatan, dan penghargaan, sementara bentuk lingkungan pekerjaan berupa kondisi kerja, pembagian kerja, status, dan kebijakan.

Maka dari beberapa uraian di atas dapat disimpulkan bahwa kompensasi terdiri dari dua jenis yaitu kompensasi langsung dan kompensasi tidak langsung. Kompensasi langsung dapat berupa gaji, upah, komisi, bonus; dan kompensasi tidak langsung dapat berupa asuransi, bantuan sosial, 
Roni Faslah \&: Pengaruh Kompensasi dan Pelatihan Terhadap Produktivitas Kerja Pada Karyawan

uang cuti, uang pensiun, pendidikan, uang lembur, tunjangan istri/anak, bantuan biaya transportasi, insentif dan lain-lain.

Berdasarkan seluruh uraian di atas dapat disimpulkan bahwa kompensasi adalah imbalan yang diberikan oleh perusahaan kepada karyawan sebagai balas jasa sesuai dengan kontribusinya terhadap perusahaan yang dapat berbentuk langsung berupa gaji, komisi, dan bonus, serta tidak langsung berupa asuransi, bantuan sosial, uang lembur, tunjangan, bantuan biaya transportasi, insentif dan lain-lain.

\section{Pelatihan}

Setiap

perusahaan

memerlukan karyawan yang kompeten dalam kegiatan operasionalnya demi mencapai tujuan. Karyawan yang terlatih dan memiliki pengalaman tentu dibutuhkan perusahaan. Hal ini menyebabkan banyak perusahaan melakukan pelatihan terhadap karyawannya untuk bisa menjadi lebih baik dalam bekerja. Pelatihan merupakan komponen yang sangat penting untuk meningkatkan daya saing perusahaan.

Pelatihan memiliki tujuan untuk mengembangkan sikap, tingkah laku, keterampilan dan pengetahuan dari karyawan. Hal ini karena setiap pekerjaan yang dilakukan karyawan sekecil apapun akan berpengaruh terhadap tujuan perusahaan.

Menurut Gomes pelatihan adalah setiap usaha untuk memperbaiki performansi pekerja pada suatu pekerjaan tertentu yang sedang menjadi tanggung jawabnya atau satu pekerjaan yang ada kaitannya dengan pekerjaannya. Sehingga dengan adanya pelatihan, karyawan diharapkan dapat melakukan perubahan cara bekerja mereka menjadi lebih baik dan cepat dalam menyelesaikan tugas yang dibebankan oleh perusahaan.

Menurut Milkovich dan Boudreau, pelatihan mengandung pengertian, "Training is a systematic process of changing the behavior, knowledge, and motivation of present employees to improve the match between employee characteristic and employment requirement". (Pelatihan adalah proses yang sistematis dari perubahan perilaku, pengetahuan, dan motivasi pekerja dalam kehadiran untuk memperbaiki kesesuaian antara karakteristik karyawan dengan standar pekerjaan.) 
Mengutip pendapat Andrew E. Sikula yang mendefinisikan pelatihan adalah "suatu proses pendidikan jangka pendek yang mempergunakan prosedur sistematis dan terorganisir dimana pegawai non manajerial mempelajari pengetahuan dan keterampilan teknis dalam tujuan terbatas".

Didukung pula oleh pendapat menurut Ambar dan Rosidah (2009) yang memberikan definisi pelatihan yaitu "proses sistematik pengubahan perilaku para pegawai dalam suatu arah guna meningkatkan tujuantujuan organisasional".

Pendapat-pendapat di atas menjelaskan bahwa pelatihan merupakan serangkaian kegiatan yang telah dipersiapkan secara sistematis dan terorganisir dalam rangka meningkatkan keahlian, pengetahuan, motivasi karyawan, keterampilan ataupun perubahan perilaku karyawan dalam bekerja. Dengan mengikuti pelatihan, karyawan diharapkan dapat menambah ilmu pengetahuan, wawasan, serta tata cara kerja yang baik dan benar yang dapat diterapkan ke dalam bidang pekerjaannya masing-masing.

Wilson Bangun (2012) mengemukakan pendapatnya tentang pelatihan yaitu "suatu proses memperbaiki keterampilan kerja karyawan untuk membantu pencapaian tujuan perusahaan".

Dari penjelasan di atas dapat disimpulkan bahwa pelatihan mempunyai tujuan untuk mengembangkan keahlian, keterampilan, kecakapan, pengetahuan dan perilaku karyawan dalam bekerja. Hal ini karena setiap pekerjaan yang dilakukan karyawan sekecil apapun akan berpengaruh terhadap tujuan perusahaan. Selain itu pelatihan juga bertujuan untuk melakukan perubahan cara bekerja karyawan agar menjadi lebih baik dan cepat dalam menyelesaikan tugas yang dibebankan.

Pelatihan yang baik adalah suatu proses yang bukan saja untuk memperbaiki pengetahuan dan keterampilan secara spesifik, tetapi juga harus mampu mengubah kebiasaan, kecakapan, dan sikap karyawan saat bekerja. Apabila karyawan memiliki keterampilan dan pengetahuan yang baik namun tidak bersikap dengan benar dan memiliki kebiasaan yang buruk terhadap pekerjaan, maka hasil pekerjaan pun tidak akan maksimal. Maka seorang karyawan yang memiliki kapabilitas yang tinggi dalam hal keterampilan,

pengetahuan, 
Roni Faslah \&: Pengaruh Kompensasi dan Pelatihan Terhadap Produktivitas Kerja Pada Karyawan

kecakapan, kebiasaan, dan sikap dalam pelaksanaan pekerjaannya akan dapat membantu pencapaian tujuan-tujuan perusahaan.

Setiap pelatihan harus terlebih dahulu ditetapkan secara jelas sasaran yang ingin dicapainya. Jika sasaran yang ingin dicapai adalah untuk meningkatkan pengetahuan, mungkin dapat dilakukan dengan cara memberi ceramah atau dalam kelas, jika sasarannya untuk meningkatkan keterampilan maka cara yang digunakan adalah dengan melatih karyawan langsung dalam praktik kegiatan pekerjaan.

Pelatihan karyawan diperlukan untuk mengatasi kesenjangan antara kualitas pelaksanaan tugas dengan standar kualitas minimal yang diperlukan, serta untuk meningkatkan kualitas kerja dalam rangka mempersiapkan karyawan yang lebih produktif. Pelatihan yang akan diberikan, tergantung dari apa yang dinilai masih kurang, apa yang ingin ditingkatkan, serta apa yang dianggap perlu dipersiapkan untuk karyawan yang bersangkutan.

Menurut Veithzal Rivai (2004), kriteria yang efektif digunakan untuk mengevaluasi kegiatan pelatihan adalah yang berfokus pada outcome (hasil akhir).
Dalam pelatihan perlu memperhatikan hal berikut ini:

1) Reaksi dari peserta pelatihan terhadap proses dan isi kegiatan pelatihan.

2) Pengetahuan atau proses belajar yang diperoleh melalui pengalaman pelatihan.

3) Perubahan perilaku yang disebabkan karena kegiatan pelatihan.

4) Hasil atau perbaikan yang dapat diukur baik secara individu maupun organisasi,seperti makin rendahnya turnover (berhenti kerja), makin sedikit kecelakaan, makin kecilnya ketidakhadiran, makin menurunnya kesalahan kerja, makin efisiennya penggunaan waktu dan biaya, serta makin produktifnya karyawan, dan lain-lain.

Lebih lanjut Ikka Kartika (2011) berpendapat bahwa hasil pelatihan yaitu mencakup peningkatan/perubahan

pengetahuan, sikap, dan keterampilan peserta pelatihan, penerapan serta dampaknya terhadap perubahan atau peningkatan kinerja peserta pelatihan serta manfaatnnya bagi organisasi/lembaga secara menyeluruh. 


Dengan demikian, kegiatan
pelatihan pada dasarnya
dilaksanakan untuk menghasilkan
perubahan tingkah laku dari orang-
orang yang mengikuti pelatihan. Perubahan tingkah laku yang dimaksud disini adalah dapat berupa bertambahnya pengetahuan, keahlian, keterampilan, dan perubahan sikap.

Dari seluruh uraian di atas dapat disimpulkan bahwa pelatihan adalah suatu perubahan yang terencana dan tersusun secara sistematis untuk memperbaiki performansi pekerjaan karyawan dengan cara mengembangkan keterampilan, pengetahuan dan sikap.

Setiap perusahaan akan selalu berupaya agar para karyawan yang terlibat dalam kegiatan perusahaan dapat memberikan prestasi dalam bentuk produktivitas kerja yang tinggi untuk mewujudkan tujuan yang telah ditetapkan. Produktivitas kerja penting dalam meningkatkan dan mempertahankan perusahaan dalam hal menghasilkan barang atau jasa.

Pada dasarnya, produktivitas kerja tidak terlepas dari peningkatan mutu tenaga kerja sebagai sumber daya manusia yang sangat menentukan bagi kelangsungan hidup perusahaan. Produktivitas kerja berkaitan dengan memproduksi keluaran secara efektif dan efisien dan khususnya ditujukan pada hubungan keluaran dengan masukan yang digunakan untuk memproduksi keluaran tersebut.

Banyak hal yang mempengaruhi produktivitas kerja, diantaranya yaitu kompensasi dan pelatihan. Kompensasi sangat penting bagi karyawan itu sendiri sebagai individu, karena besarnya kompensasi merupakan pencerminan atau ukuran nilai dari pekerjaan karyawan itu sendiri. Dengan adanya kompensasi yang layak diterima oleh karyawan, maka mereka akan bekerja lebih maksimal, sehingga produktivitas kerjanya juga akan meningkat yang akan menguntungkan bagi perusahaan.

Hal ini seperti dikemukakan oleh Wilson Bangun (2010) bahwa slah satu cara manajer untuk meningkatkan produktivitas kerja, kepuasan kerja, dan motivasi adalah melalui kompensasi. Dipertegas oleh Tjuju Yuniarsih yang menjelaskan bahwa, kompensasi berfungsi sebagai faktor motivasi dalam meningkatkan kinerja dan 
Roni Faslah \&: Pengaruh Kompensasi dan Pelatihan Terhadap Produktivitas Kerja Pada Karyawan

produktivitas kerja karyawan (2011).

Perusahaan memberikan kompensasi kepada para karyawan atas jasa yang mereka sumbangkan pada pekerjaannya. Karyawan menyumbangkan apa yang menurut mereka berharga, baik tenaga maupun pengetahuan yang dimiliki untuk perusahaan. Apabila karyawan merasa puas terhadap kompensasi yang diberikan, karyawan akan bekerja dengan maksimal dan akan meningkatkan produktivitas kerjanya.

Dalam hal ini, Suwatno (2011) menyatakan bahwa "kompensasi yang layak akan memberikan rangsangan serta memotivasi karyawan untuk memberikan kinerja terbaik dan menghasilkan produktivitas kerja yang optimal". Bagi karyawan, kompensasi merupakan harapan dan masa depan untuk menempuh kehidupan yang dijalani. Dengan adanya pemberian kompensasi dapat membuat karyawan merasa hak-haknya telah dipenuhi oleh perusahaan. Sehingga bermanfaat untuk membangun dan meningkatkan produktivitas kerja karyawan.

Sebagaimana yang telah diungkapkan di atas bahwa kompensasi memiliki pengaruh terhadap karyawan di suatu perusahaan. Ike Kusdyah (2008) berpendapat bahwa "Apabila karyawan memandang bahwa bila kompensasi tidak memadai maka produktivitas, prestasi kerja, dan kepuasan kerja karyawan akan turun". Kompensasi karyawan mengacu pada semua bentuk pembayaran atau penghargaan akan karyawan yang timbul dari apa yang mereka kerjakan. Pada saat perusahaan memberikan kompensasi kepada karyawan yang memadai sesuai dengan kontribusinya, secara langsung akan berdampak pada kenaikan produktivitas kerja.

Selain itu, suatu perusahaan perlu menyadari pentingnya pelatihan karyawan agar menjadi tenaga kerja yang produktif. Tenaga kerja yang produktif akan meningkatkan kualitas dan kuantitas produk dalam perusahaan. Hal ini membuat pelaksanaan pelatihan dalam rangka meningkatkan produktivitas kerja menjadi salah satu aspek cukup penting untuk dilakukan oleh perusahaan.

Sejalan dengan pendapat Tjutju Yuniarsih ( 2011) bahwa, "Pelatihan tidak saja menambah pengetahuan karyawan, tetapi juga 
Roni Faslah \&: Pengaruh Kompensasi dan Pelatihan Terhadap Produktivitas Kerja Pada Karyawan

meningkatkan keterampilan yang mengakibatkan peningkatan produktivitas kerja". Pelatihan akan membantu karyawan dalam mengembangkan kemampuan dan juga membantu karyawan dalam memahami suatu pengetahuan praktis serta menerapkannya guna meningkatkan keterampilan yang diperlukan oleh perusahaan. Dengan begitu, tujuan perusahaan akan tercapai dan produktivitas kerja akan mengalami peningkatan.

Didukung oleh pendapat Toni Setiawan (2012) bahwa "Tujuan pelatihan sumber daya manusia adalah meningkatkan kualitas kerja dan meningkatkan produktivitas kerja". Dipertegas oleh Notoatmodjo (2003) bahwa, "Tujuan pelatihan utamanya adalah meningkatkan produktivitas atau hasil kerja pegawai, atau dengan kata lain adalah untuk meningkatkan efektivitas dan efisiensi kerja tiap pegawai". Pelatihan ini dimaksudkan sebagai investasi sebuah perusahaan dalam peningkatan kualitas sumber daya manusia, khususnya dalam meningkatkan efektivitas dan efisiensi kerja tiap pegawai.

Wilson Bangun (2012) mengemukakan pendapat bahwa manfaat dari pelatihan karyawan dengan semakin terampilnya karyawan akan mengurangi penggunaan biaya pada pekerjaannya. Dengan demikian akan berpengaruh secara langsung pada peningkatan produktivitas". Dengan pelatihan sebenarnya para karyawan tidak hanya diajarkan lebih cepat dan lebih baik, tetapi juga bagaimana menghemat penggunaan biaya saat bekerja, dengan harapan sisa bahan yang terbuang menjadi berkurang dan kerusakan barang menjadi lebih kecil. Sehingga hal tersebut akan berdampak langsung pada peningkatan produktivitas.

Selanjutnya Sedarmayanti (2011) berpendapat bahwa banyak aktivitas yang dilaksanakan dalam sistem sumber daya manusia dirancang untuk mempengaruhi produktivitas individual atau organisasional. Penggajian, sistem penilaian, pelatihan, seleksi, desain pekerjaan, dan kompensasi adalah aktivitas sumber daya manusia yang berkaitan langsung dengan produktivitas. Didukung oleh Hadiyana (2009), tingkat pendidikan, pelatihan, motivasi dan kompensasi mempunyai pengaruh yang signifikan dengan produktivitas kerja. 
Sebagaimana teori yang telah dikemukakan di atas maka jelaslah kompensasi dan pelatihan merupakan salah satu faktor yang dapat meningkatkan produktivitas kerja. Dengan adanya kompensasi dan pelatihan yang baik maka karyawan akan memiliki produktivitas kerja yang optimal pula.

\section{METODE PENELITIAN}

Tujuan penelitian ini adalah untuk mendapatkan pengetahuan berdasarkan data-data yang tepat (sahih, benar, valid) dan dapat dipercaya (dapat diandalkan, reliable) tentang:

1. Pengaruh kompensasi terhadap produktivitas kerja pada karyawan PT Asaba Jakarta.

2. Pengaruh pelatihan terhadap produktivitas kerja pada karyawan PT Asaba Jakarta.

3. Pengaruh kompensasi dan pelatihan terhadap produktivitas kerja pada karyawan PT Asaba Jakarta.

Penelitian ini dilaksanakan di PT Asaba yang beralamat di Jalan Ir. H. Juanda, Jakarta Pusat, 10120. Alasan PT Asaba dijadikan objek penelitian karena menurut pengamatan peneliti bahwa produktivitas kerja PT Asaba dipengaruhi oleh kompensasi dan pelatihan.

Penelitian ini dilakukan selama dua bulan, terhitung dari bulan Mei 2014 sampai dengan Juni 2014. Waktu tersebut merupakan waktu yang efektif bagi peneliti untuk melakukan penelitian sehingga peneliti dapat memfokuskan diri dari penelitian.

Metode yang digunakan dalam penelitian ini adalah metode survei dengan pendekatan korelasional untuk mengetahui hubungan antara tiga variabel, yaitu variabel bebas dan variabel terikat.

Dalam penelitian ini yang menjadi variabel bebas (Variabel $X_{1}$ ) kompensasi dan (Variabel $\mathrm{X}_{2}$ ) pelatihan sebagai variabel yang mempengaruhi dan variabel terikatnya (Variabel Y) adalah produktivitas kerja sebagai variabel yang dipengaruhi.

Dalam penelitian ini yang menjadi populasi adalah seluruh karyawan PT Asaba yang berjumlah 200 karyawan. Sedangkan populasi terjangkaunya adalah karyawan pada bagian Teknik PT Asaba yang berjumlah 70 karyawan, maka sampel yang diambil sebanyak 58 responden. Berdasarkan tabel Isaac \& Michael(Soegiyono, 2006) sampel penentuan dengan taraf kesalahan 
5\%. Menurut Sudjana suatu sampel memiliki distribusi normal apabila memiliki ukuran sampel $\mathrm{n}>30$. Dalam penelitian ini jumlah sampel yang digunakan lebih dari 30, sehingga sudah memenuhi asumsi distribusi normal.

Teknik pengambilan sampel yang digunakan adalah teknik acak sederhana (simple random sampling), yaitu dalam menentukan anggota sampel, penelitian mengambil secara acak dengan menggunakan undian yang ada dalam populasi.

Teknik analisis data dilakukan dengan menganalisis data, dilakukan estimasi parameter model regresi yang akan digunakan yaitu regresi berganda. Pengolahan data dalam penelitian ini menggunakan program SPSS versi 16.0.

\section{HASIL PENELITIAN}

Berdasarkan hasil penelitian regresi berganda, secara bersamasama pengaruh Kompensasi dan Pelatihan terhadap Produktivitas
Kerja diperoleh koefisien determinasi dengan melihat $\mathrm{R}^{2}$ sebesar 0,946 yang artinya pengaruh variabel independen Kompensasi dan Pelatihan terhadap variabel dependen (Produktivitas Kerja) sebesar 94,6\% Sedangkan sisanya sebesar 5,4\% dipengaruhi atau dijelaskan oleh variabel lain yang tidak diteliti.

Kemudian dari hasil uji hipotesis kedua variabel bebas yaitu Kompensasi dan Pelatihan secara serentak memiliki pengaruh terhadap Produktivitas Kerja yang dilihat dari $F_{\text {hitung }} 483,263>F_{\text {tabel }}$ 3,165 . Lalu secara parsial variabel kompensasi memiliki $t_{\text {hitung }}=1,715$ dan pelatihan memiliki $t_{\text {hitung }}=$ 17,653 dengan $t_{\text {tabel }}=1,673$ dimana secara terpisah menyatakan signifikasinya ( $t_{\text {hitung }}>t_{\text {tabel }}$ ) artinya masing-masing variabel bebas yaitu kompensasi dan pelatihan memiliki pengaruh positif yang signifikan terhadap variabel terikat yaitu produktivitas kerja. 
Tabel 1

Tabel Regresi (Persamaan Regresi Berganda)

\begin{tabular}{|c|c|c|c|c|c|c|c|c|}
\hline \multirow{2}{*}{\multicolumn{2}{|c|}{ |Model }} & \multicolumn{2}{|c|}{$\begin{array}{l}\text { Unstandardized } \\
\text { Coefficients }\end{array}$} & \multirow{2}{*}{\begin{tabular}{|c|}
$\begin{array}{c}\text { Standardize } \\
\mathrm{d} \\
\text { Coefficients }\end{array}$ \\
Beta \\
\end{tabular}} & \multirow[b]{2}{*}{$\mathrm{t}$} & \multirow[b]{2}{*}{ Sig. } & \multicolumn{2}{|c|}{$\begin{array}{l}\text { Collinearity } \\
\text { Statistics }\end{array}$} \\
\hline & & B & $\begin{array}{l}\text { Std. } \\
\text { Error }\end{array}$ & & & & Tolerance & VIF \\
\hline \multirow[t]{3}{*}{1} & (Constant) & .384 & 2.770 & & .139 & .890 & & \\
\hline & $\begin{array}{l}\text { Kompensasi } \\
(\mathrm{X} 1)\end{array}$ & 2.644 & 1.541 & .088 & 1.715 & .092 & .375 & 2.667 \\
\hline & Pelatihan (X2) & 7.010 & .397 & .902 & 17.653 & .000 & .375 & 2.667 \\
\hline
\end{tabular}

a. Dependent Variable: Produktivitas $(Y)$

Nilai-nilai untuk persamaan positif antara kompensasi dengan regresi dapat dilihat pada tabel di atas sehingga dapat diperoleh produktivitas kerja, semakin persamaan sebagai berikut: $\hat{\mathrm{Y}}=$ $0,384+2,644 X_{1}+7,010 X_{2}$

Pada tabel koefisien di atas, meningkat kompensasi maka akan semakin tinggi produktivitas kerjanya.

Nilai koefisien $\left(b_{2}\right)$ sebesar nilai konstanta sebesar 0,384, artinya jika Kompensasi dan Pelatihan nilainya 0 , maka Produktivitas Kerja nilainya adalah 0,384 .

Nilai koefisien $\left(b_{1}\right)$ sebesar 2,644 artinya jika pelatihan nilainya tetap dan kompensasi mengalami kenaikan 1 poin, maka produktivitas kerja akan meningkat sebesar 2,644 dengan asumsi variabel independen lain nilainya tetap. Koefisien bernilai positif artinya terdapat hubungan 7,010 artinya jika kompensasi
nilainya tetap dan pelatihan nilainya ditingkatkan sebesar 1 poin, maka produktivitas kerja akan meningkat sebesar 7,010 dengan asumsi variabel independen lain nilainya tetap. Koefisien bernilai positif artinya terdapat hubungan positif antara pelatihan dengan produktivitas kerja, semakin tinggi pelatihan maka akan semakin tinggi produktivitas kerjanya.

\section{Uji Hipotesis}

\section{Uji F}


Uji $F$ digunakan untuk $\mathrm{Di}$ bawah ini disajikan hasil mengetahui pengaruh variabel perhitungan $\mathrm{Uji} F$ dengan independen secara serentak menggunakan SPSS, yaitu sebagai terhadap variabel dependen, apakah berikut: pengaruhnya signifikan atau tidak.

Tabel 2

ANOVA (Uji F)

ANOVA $^{\mathrm{b}}$

\begin{tabular}{|c|c|c|c|c|c|c|}
\hline \multicolumn{2}{|c|}{ Model } & $\begin{array}{l}\text { Sum of } \\
\text { Squares }\end{array}$ & df & $\begin{array}{c}\text { Mean } \\
\text { Square }\end{array}$ & $\mathrm{F}$ & Sig. \\
\hline \multirow[t]{3}{*}{1} & Regression & 970.188 & 2 & 485.094 & 483.263 & $.000^{\mathrm{a}}$ \\
\hline & Residual & 55.208 & 55 & 1.004 & & \\
\hline & Total & 1025.397 & 57 & & & \\
\hline
\end{tabular}

a. Predictors: (Constant), Pelatihan, Kompensasi

b. Dependent Variable: Produktivitas

Berdasarkan tabel di atas, $F_{\text {hitung }}$ sebesar 483,263 Sedangkan besarnya $F_{\text {tabel }}$ dapat dilihat pada tabel statistik pada signifikasi $5 \%$ atau 0,05 df1=k-1 atau 3-1=2, dan $\mathrm{df} 2=\mathrm{n}-\mathrm{k}-1$ atau $58-2-1=55$ Didapat $F_{\text {tabel }}$ adalah 3,165.

Dapat diketahui $F_{\text {hitung }}$ $483,263>F_{\text {tabel }} 3,165$, artinya $\mathrm{H}_{\mathrm{o}}$ ditolak, sehingga dapat disimpulkan
Kompensasi dan Pelatihan secara serentak berpengaruh terhadap Produktivitas Kerja.

\section{Uji t}

$\mathrm{Uji} \mathrm{t}$ untuk mengetahui pengaruh variabel independen secara parsial terhadap variabel dependen, apakah pengaruhnya signifikan atau tidak. 
Tabel 3

Tabel Regresi (Uji t)

Coefficients $^{\mathrm{a}}$

\begin{tabular}{|c|c|c|c|c|c|c|c|}
\hline \multirow[b]{2}{*}{ Model } & \multicolumn{2}{|c|}{$\begin{array}{c}\text { Unstandardized } \\
\text { Coefficients }\end{array}$} & \multirow{2}{*}{\begin{tabular}{|c|}
$\begin{array}{c}\text { Standardize } \\
\mathrm{d} \\
\text { Coefficients }\end{array}$ \\
Beta
\end{tabular}} & \multirow[b]{2}{*}{$\mathrm{t}$} & \multirow[b]{2}{*}{ Sig. } & \multicolumn{2}{|c|}{$\begin{array}{l}\text { Collinearity } \\
\text { Statistics }\end{array}$} \\
\hline & B & $\begin{array}{l}\text { Std. } \\
\text { Error }\end{array}$ & & & & Tolerance & VIF \\
\hline (Constant) & .384 & 2.770 & & .139 & .890 & & \\
\hline $\begin{array}{l}\text { Kompensasi } \\
(\mathrm{X} 1)\end{array}$ & 2.644 & 1.541 & .088 & 1.715 & .092 & .375 & 2.667 \\
\hline Pelatihan (X2) & 7.010 & .397 & .902 & 17.653 & .000 & .375 & 2.667 \\
\hline
\end{tabular}

a. Dependent Variable: Produktivitas (Y)

Uji t dapat dilihat dalam tabel di atas, berdasarkan hasil output tersebut diperoleh $t_{\text {tabel }}$ dapat dicari pada tabel statistic pada signifikasi $5 \%$ atau 0,05 dengan $\mathrm{df}=\mathrm{n}-\mathrm{k}-1$ atau 58-2-1 = 55, maka didapat $t_{\text {tabel }}$ sebesar 1,673.

Dapat diketahui bahwa $t_{\text {hitung }}$ dari kompensasi 1,715 $>t_{\text {tabel }} 1,673$ jadi $\mathrm{H}_{\mathrm{o}}$ ditolak, kesimpulannya yaitu kompensasi mempunyai pengaruh positif yang signifikan terhadap produktivitas kerja.

Selain itu berdasarkan hasil output di atas dapat diketahui bahwa $t_{\text {hitung }}$ dari pelatihan $17,653>$ tabel 1,673 jadi $H_{0}$ ditolak, kesimpulannya yaitu pelatihan mempunyai pengaruh positif yang signifikan terhadap produktivitas kerja.

\section{Analisis Koefisien Determinasi}

Analisis koefisien determinasi $\left(R^{2}\right)$ digunakan untuk menguur seberapa besar kemampuan suatu model menerangkan variasi variabel dependen. 
Tabel 3

Tabel Summary (Koefisien Determinasi)

Model Summary

\begin{tabular}{|l|r|r|r|r|}
\hline Model & R & R Square & $\begin{array}{c}\text { Adjusted R } \\
\text { Square }\end{array}$ & $\begin{array}{l}\text { Std. Error of } \\
\text { the Estimate }\end{array}$ \\
\hline 1 & $.973^{\mathrm{a}}$ & .946 & .944 & 1.002 \\
\hline
\end{tabular}

a. Predictors: (Constant), Pelatihan, Kompensasi

Dari tabel di atas dapat diketahui nilai $R^{2}$ adalah 0,946 . Jadi kemampuan dari variabel Kompensasi dan Pelatihan untuk menjelaskan Produktivitas Kerja secara simultan yaitu $94,6 \%$ sedangkan sisanya sebesar $5,4 \%$ dipengaruhi oleh faktor lain yang tidak diteliti.

\section{PENUTUP}

Berdasarkan hasil perhitungan yang telah dilakukan, maka dapat diinterpretasikan bahwa kompensasi mempengaruhi produktivitas kerja artinya semakin tinggi kompensasi maka semakin tinggi pula produktivitas kerja. Pelatihan juga mempengaruhi produktivitas kerja., semakin tinggi pelatihan maka semakin tinggi pula produktivitas kerja

Demikian pula sebaliknya, semakin rendah kompensasi maka semakin rendah pula produktivitas kerja. Kemudian, semakin rendah pelatihan semakin rendah pula produktivitas kerja. Dan pada intinya, apabila kompensasi dan pelatihan semakin tinggi, maka semakin tinggi pula produktivitas kerja.

\section{DAFTAR PUSTAKA}

Akhmad Subekhi dan Moh. Jauhar. 2009. Pengantar Manajemen Sumber Daya Manusia (MSDM), (Jakarta: Prestasi Pustaka.

Ambar Teguh dan Rosidah, 2009. Manajemen Sumber Daya Manusia, (Yogyakarta: Graha Ilmu.

Danang Sunyoto. 2012. Manajemen Sumber Daya Manusia. Yogyakarta: CAPS.

Faustino Cardoso Gomes, 2003. Manajemen Sumber Daya Manusia, (Yogyakarta: ANDI. 
Hadiyana. 2009, Analisis Pengaruh

Tingkat Pendidikan,

Pelatihan, Motivasi dan Kompensasi terhadap

Produktivitas Kerja Guru SMK Se-kota Jayapura, Jurnal Uniyap: Jurnal IImu Pengetahuan dan Teknologi, Vol. II, No: 5, Agustus 2009

Ike Kusdyah R 2008. , Manajemen

Sumber Daya Manusia, Yogyakarta: CV ANDI OFSET, Ikka Kartika. 2011, Mengelola Pelatihan Partisipatif, (Bandung: Alfabeta.

Malayu S.P. Hasibuan, 2010. Organisasi dan Motivasi Dasar Peningkatan Produktivitas, (Jakarta: PT Bumi Akasara.

Muchtar A.F, 2010. Panduan Praktis Strategis Memenangkan Persaingan Usaha dengan Menysusun Business Plan, Jakarta: Elex Media Komputindo.

Prijono Tjiptoherijanto dan Laila Nagib, 2008. Pengembangan Sumber Daya Manusia: diantara Peluang dan Tantangan, Jakarta: LIPI.

Sedarmayanti, 2010. Manajemen Sumber Daya Manusia, Bandung: Refika Aditama.
Sedarmayanti, 2011. Tata Kerja dan Produktivitas Kerja, Bandung: CV. Mandar Maju.

Sjafri Mangkuprawira, 2004. Manajemen Sumber Daya Manusia Strategik, (Bogor: Ghalia Indonesia.

Soekidjo Notoatmodjo, 2003. Pengembangan Sumber Daya Manusia, Jakarta: PT RINEKA CIPTA.

Suwatno dan Donni Juni, 2011. Manajemen SDM dalam Organisasi Publik dan Bisnis, Bandung: Alfabeta.

T. Hani Handoko, 2011. Manajemen Personalia dan Sumberdaya Manusia, Yogyakarta: BPFE.

Tjuju Yuniarsih dan Suwatno 2011. Manajemen Sumber Daya Manusia, Bandung: Alfabeta.

Toni Setiawan. 2012, Manajemen Sumber Daya Manusia, Jakarta: Platinum.

Veithzal Rivai, 2004. MSDM untuk Perusahaan dari Teori ke Praktek, Jakarta: PT Raja Grafindo Persada.

Wilson Bangun, 2012. Manajemen Sumber Daya Manusia, Jakarta: Erlangga. 